Fordham Law School

FLASH: The Fordham Law Archive of Scholarship and History

Faculty Scholarship

2012

\title{
Corporate Governance, Corporate and Employment Law, and the Costs of Expropriation
}

\author{
Giulio Ecchia \\ University of Bologna, giulio.ecchia@unibo.it \\ Martin Gelter \\ Fordham University School of Law, mgelter@law.fordham.edu \\ Piero Pasotti \\ University of Bologna, piero.pasotti@unibo.it
}

Follow this and additional works at: https://ir.lawnet.fordham.edu/faculty_scholarship

Part of the Law Commons

\section{Recommended Citation}

Giulio Ecchia, Martin Gelter, and Piero Pasotti, Corporate Governance, Corporate and Employment Law, and the Costs of Expropriation, 8 Rev. L. Econ. 1 (2012)

Available at: https://ir.lawnet.fordham.edu/faculty_scholarship/903

This Article is brought to you for free and open access by FLASH: The Fordham Law Archive of Scholarship and History. It has been accepted for inclusion in Faculty Scholarship by an authorized administrator of FLASH: The Fordham Law Archive of Scholarship and History. For more information, please contact tmelnick@law.fordham.edu. 


\section{ecgi}

\section{Corporate Governance, Corporate and Employment Law, and the Costs of Expropriation}

Law Working Paper $N^{\circ} .128 / 2009$

July 2009
Giulio Ecchia

University of Bologna

Martin Gelter

Fordham University School of Law and ECGI

Piero Pasotti

University of Bologna

(C) Giulio Ecchia, Martin Gelter and Piero Pasotti 2009. All rights reserved. Short sections of text, not to exceed two paragraphs, may be quoted without explicit permission provided that full credit, including (C) notice, is given to the source.

This paper can be downloaded without charge from: http://ssrn.com/abstract=1430623.

www.ecgi.org/wp 


\title{
Corporate Governance, Corporate and Employment Law, and the Costs of Expropriation
}

\author{
Working Paper $\mathrm{N}^{\circ} .128 / 2009$ \\ July 2009 \\ Giulio Ecchia \\ Martin Gelter \\ Piero Pasotti
}

We would like to thank Alessio Pacces, Holger Spamann, and the participants of the 2008 Meetings of the European Association of Law and Economics in Haifa, the SIDE-ISLE Conference in Bologna, the Canadian Law and Economics Association in Toronto, the 2009 EMLE Workshop in Hamburg, and the 19th Annual Meeting of the American Law and Economics Association in San Diego for comments and criticism. Martin Gelter gratefully acknowledges financial support provided by a visiting fellowship of the Institute of Advanced Studies at the University of Bologna, and by a Terence M. Considine Fellowship through the John M. Olin Center for Law, Economics and Business at Harvard Law School.

(C) Giulio Ecchia, Martin Gelter and Piero Pasotti 2009. All rights reserved. Short sections of text, not to exceed two paragraphs, may be quoted without explicit permission provided that full credit, including (C) notice, is given to the source. 


\title{
Abstract
}

We set up a model to study how ownership structure, corporate law and employment law interact to set the incentives that influence the decision by the large shareholder or manager effectively controlling the firm to divert resources from minority shareholders and employees. We suggest that agency problems between the controller and other investors and holdup problems between shareholders and employees are connected if the controller bears private costs of "expropriating" these groups. Corporate law and employment law may therefore somethimes be substitutes; employees may benefit from better corporate law intended to protect minority shareholder, and vice versa. Our model has implications for the domestic and comparative study of corporate governance structure and addresses, among other things, the question whether large shareholders are better able to "bond" with employees than dispersed ones, or whether the separation of ownership facilitates longterm relationships with labor.

Keywords: corporate governance, ownership structure, corporate law, employment law, minority shareholders, holdup problem, stakeholders, labor

JEL Classifications: G30, K22

\author{
Giulio Ecchia \\ University of Bologna - Dept. of Economics \\ Piazza Scaravilli 2 \\ 40126 Bologna, \\ Italy \\ e-mail: giulio.ecchia@unibo.it \\ Martin Gelter \\ Fordham University School of Law \\ 140 West 62nd Street \\ New York, NY 10023 \\ United States \\ phone: 646-312-8752 \\ e-mail: mgelter@law.fordham.edu \\ Piero Pasotti \\ University of Bologna - Dept. of Economics \\ Piazza Scaravilli 2 \\ 40126 Bologna, \\ Italy \\ e-mail: piero.pasotti@unibo.it
}


ISSN 1936-5349 (print)

ISSN 1936-5357 (online)

\title{
HARVARD
}

JOHN M. OLIN CENTER FOR LAW, ECONOMICS, AND BUSINESS

FELLOWS' DisCUSSION PAPER SERIES

\author{
CORPORATE GOVERNANCE, CORPORATE \\ AND EMPLOYMENT LAW, AND THE COSTS \\ OF EXPROPRIATION
}

\author{
Giulio Ecchia, Martin Gelter, \\ Piero Pasotti
}

Discussion Paper No. 29

$5 / 2009$

Harvard Law School

Cambridge, MA 02138

Contributors to this series are John M. Olin Fellows or Terence M.

Considine Fellows in Law and Economics at Harvard University.

This paper can be downloaded without charge from:

The Harvard John M. Olin Fellow's Discussion Paper Series:

http://www.law.harvard.edu/programs/olin_center/ 


\section{Introduction}

The interaction between finance and labor has been studied with increasing interest in recent years (Pagano \& Volpin, 2008). One aspect of the debate is the possibility of employees (or other stakeholders) making firm-specific investment in human capital from which the firm will benefit. However, stakeholders may be deterred from such investment if they are not adequately rewarded for it because managers or shareholders will expropriate their (quasi-)rents (Shleifer \& Summers, 1988). This paper seeks to contribute to the literature on this issue by trying to identify the circumstances under which such holdup situations are likely to occur by linking them to corporate ownership and governance structures prevalent in different firms and different countries. We also analyze how holdup issues with respect to workers may be connected to agency problems from which shareholders suffer. ${ }^{1}$ In any case, even if one does not believe specific human capital to be an important issue for corporate governance, our model may still be of interest for the distributive issue of how rents produced by the corporation are assigned to managers, large and small shareholders, and workers.

The bulk of the corporate governance literature is concerned with private benefits of control, which allows the controller of the firm to usurp part of the corporate patrimony that minority investors would have expected to participate in (Shleifer \& Vishny, 1997). It is part of the conventional wisdom in comparative corporate governance that agency problems differ strongly between firms with dispersed and concentrated ownership, the main issue being managerial agency problems in the first and agency problems resulting from the presence of a large shareholder in the second case (e.g. Shleifer \& Vishny, 1997:758-761), the effect being that policymakers in different countries will have to look at different issues depending on which kind of ownership predominates in a particular corporate governance system. Differences in the firm's interaction with other stakeholders, such as workers, are a less well researched issue. From an empirical point of view it is well known that in the OECD countries there is a significant negative cross-country correlation between workers' protection and ownership dispersion (Belloc \& Pagano, 2009). It is not clear whether there is a causal relation between the two factors, or whether they constitute a set of institutional complements. Roe (Roe, 2003) suggests that stronger employment law and social democratic policies in general might increase the incentives to concentrate ownership due to exacerbated managerial agency problems, while other scholars have recently emphasized a possible (additional) opposite causal relation with pro-labor laws as a reaction to the concentration of power and corporate ownership (Gelter, 2009; Belloc \& Pagano, 2009).

The latter direction of causality is based on assumptions that are not unanimously held in the comparative corporate governance literature.

\footnotetext{
${ }^{1}$ Our model does not build directly on the technical literature on holdup models. As usually understood; we use the term "holdup" to refer to opportunism to the detriment of workers in general. In some sense our model is more general than the holdup case; our model applies to any situation in which some kind of contractual incompleteness allows for ex-post expropriation of workers and shareholders.
} 
While some authors have suggested that large shareholders may be better able to exploit non-shareholder constituencies (Charreaux \& Desbrières, 2001:758; Jackson, 2005:116), another part of the literature hypothesizes that large shareholders may be better able to commit to the firm in the long run, thus assuring to stakeholders that specific investment can safely be made without needing to fear ex-post expropriation of rents (e.g. Aguilera \& Jackson, 2003:183; Woolcock, 1996:451). On the one hand, one could argue that this proposition is counterintuitive, considering that shareholders presumably are the financial beneficiary of holdup of stakeholders. Large, controlling shareholders (or coalitions of large shareholders) who are able to influence management, could therefore both be in a good position and have strong incentives to "expropriate" workers. By contrast, the literature suggesting that this long-commitment to employees is prevalent seems to presume that managers in dispersed ownership systems are forced by market mechanisms, most of all by hostile takeovers, to expropriate workers where shareholders can benefit from it financially (e.g. Franks \& Mayer, 1998:728-729). ${ }^{2}$

In reality, this assumption often seems not to be justified. In recent years, legal scholars have increasingly found that managers in the US, the paradigmatic dispersed ownership system, are typically relatively insulated from shareholders and often do not have strong incentives to pursue shareholder wealth maximization. In particular, there is persuasive evidence that Delaware corporate law has developed to offer managers highly effective means to shield themselves against hostile takeovers (Bebchuk et al., 2002). Scholars of comparative corporate law point out that the US corporate governance system, taking both the law and financial structures into account, provides an unusual degree of insulation of managers (Hansmann \& Kraakman, 2004:53-54). ${ }^{3}$ While this aspect of US corporate governance often leads to considerable criticism (e.g. Bebchuk \& Cohen, 2005), others have attempted to find efficiency explanations (Bainbridge, 2003; Elhauge, 2005). On the basis of Rajan \& Zingales' contribution to the theory of the firm (Rajan \& Zingales, 1998), Margaret Blair and Lynn Stout have developed a team production theory of corporate law (Blair \& Stout, 1999, Blair \& Stout, 2006), the core claim of which is that the insulation of managers from shareholders is efficient because it protects employees and other stakeholders from holdup. Similarly, others have suggested that taking the firm public reduces the possibility of shareholder intervention, thus effectively allowing managers and/or employees some leeway to capture private benefits if the firm is successful (Burkart et al., 1997, Brealey et al., 2006:949). This kind of argument has problems in firms or corporate governance systems characterized by concentrated ownership. In such systems, other mechanisms such as codetermination or employment law may help to protect stakeholders from holdup (cf. Fauver \& Fuerst, 2006:679-680; Armour \& Deakin, 2003:445-452). Thus, it has been

\footnotetext{
${ }^{2}$ This is the situation envisioned by the well-known contribution of Shleifer \& Summers, 1988 regarding hostile takeovers in the US.

${ }^{3}$ In fact, the situation seems to be very different in the UK, the second important dispersed ownership system, where takeover law has provided an obligations for managers to stay neutral in takeover contests since the late 1960s. See Armour \& Skeel, 2007.
} 
suggested that pro-employee laws may be relatively more desirable in corporate governance systems with concentrated ownership than in dispersed ones, and in dispersed ownership systems with more vibrant markets for hostile takeovers than in ones where managers can effectively shield themselves (Gelter, 2009). ${ }^{4}$

The two views on the effects of ownership structure on stakeholders seem to be irreconcilable at first glance, as two mutually exclusive phenomena (the presence of large blockholders or ownership dispersion) are interpreted as the solution for the problem of long-term commitment to stakeholders. Our paper seeks to provide a reconciliation on the basis of an identification of the reasons why the effective "controller" of a firm (either a manager or a large shareholder) may refrain from expropriating either shareholders or stakeholders, or both. We argue that expropriating either shareholders or stakeholders comes at a cost. Depending on the respective corporate and labor laws, some resources must be invested in expropriation. Many of these costs are borne by the firm. While the controller always can expect some financial benefit from expropriation, we argue that sometimes she has to bear some additional (private) costs of expropriation herself, which creates a countervailing incentive. On the basis of these costs, whose real-life interpretation we discuss in some detail below, we identify various prototypical "structures" of firms that depend on the nature of the private costs borne by the controller. Thus, the extent to which shareholders and/or employees are "expropriated" will depend (1) on the controller's ownership share, (2) on the strength of the applicable protecting the respective group, and (3) on the presence of private "costs of expropriating" not borne by the firm, but the controller. Ultimately, whether blockholders or the managers of a dispersed firm are more likely to engage in long-term bonding with employees will depend on their private cost of expropriation (although the controlling shareholders' larger financial stake certainly has an impact).

At the same time, our model shows how the expropriation of (minority) shareholders and stakeholders are connected. In the presence of a positive cost of expropriation, employees may benefit from laws intended to protect shareholders, and vice versa. Holdup gains from putting pressure on employees result in higher ex post shareholder value (in the form of higher dividends or stock price). This implies that the controller's incentive to be tough on employees depends on the extent to which he has to share these gains with minority shareholders. In other words, if legal protection against private benefits of control is strong, the incentive to engage in holdup of employees will be reduced, since the controller will have to share a large proportion of holdup gains with minority shareholders. Thus, corporate law and employment law may to some extent be substitutes, and interests of investors and employees may sometimes be aligned, which may explain the "coalitions" between these two groups against managers that some scholars have identified. By contrast, the effects of increased labor protection on minority shareholders depend on the circumstances.

\footnotetext{
${ }^{4}$ Legal systems often distinguish between (individual) employment law and (collective) labor law. We use both terms interchangeably, as our model does not distinguish between these two bodies of law.
} 


\section{The model}

\subsection{General framework}

Our model attempts to integrate specific investment by workers, holdup of workers by the controller of the firm, and expropriation of minority investors by the controller of the firm. The person in control of the firm, to which we refer to as the manager, could, on one hand, represent senior management in a publicly traded firm with dispersed ownership, or, on the other hand a single large shareholder or a coalition of large blockholders effectively controlling a firm through concentrated ownership blocks. In the second case, it is assumed that conflicts of interests between a third-party manager and the controlling shareholder are negligible; we consider only conflicts of interests between controlling and non-controlling shareholders as the relevant agency conflict in this case. In our model, the two archetypal types of ownership structure are distinguished by the amount of shares held by the manager.

In either case, we assume that the manager needs outside shareholders to finance the firm, and that employees make firm-specific investment (e.g. in human capital). This allows the firm to operate and to produce a surplus. The manager subsequently decides how to allocate the surplus between outside investors, employees, and himself. Both investors and employees have a baseline expectation about their share of the surplus. The manager can decide to withhold part of the expected share from these groups, to which we refer as "minority expropriation" and "employee exploitation" respectively. ${ }^{5}$ However, exploitation of either group is costly, and the manager is further constrained by corporate law and employment law.

Wages are often understood to consist of a fixed claim only. However, in our model, the wage accorded to employees and their baseline expectation is assumed to include rewards that are part of an implicit contract, such as e.g. certain types of retirement benefits, expectations regarding job security and advancement within the corporate hierarchy, and the safety of working conditions.

In the model we assume that the value of the production depends upon the effort put up by workers. We devise a two-stage game where the effort of workers is perfectly observable and the manager has the first-mover advantage ${ }^{6}$.

1. In the first stage the manager chooses the level of worker and minority expropriation.

2. In the second stage workers choose the optimal level of effort (amount of costly specific investment)

\footnotetext{
${ }^{5}$ By these terms we mean actions by managers and controlling shareholders reneging on expectations by these two groups, thereby decreasing their utility, most of all the classical agency and holdup problems familiar from contract theory.

${ }^{6}$ We try to capture in this way the asymmetric position of managers and workers. We are somehow assuming that the managers are in a stronger position either because of the hierarchic relation between managers and workers or because the manager has better information than the workers.
} 
Since everything is observable and agents are rational, the level of expropriation the manager will choose in the first stage will depend upon the effect he expects on workers' effort in the second stage.

The value of the output produced by the firm will be $x(e)$, where $e$ is the effort of the workers, $x^{\prime}>0$ and $x^{\prime \prime}<0$. Once the output is produced, the manager can decide to put up some effort to expropriate the workers (e.g. by exploiting hold up situations).

The wage earned by the worker is a share $\omega$ of the output. $w=\omega x(e)$. The effort made by the manager to exploit workers determines $\omega, \omega=\varpi-$ $\left(1-p_{L}\right) \gamma\left(c_{L}\right)$, where $\varpi$ is the share of revenues used to pay workers if the manager does not invest in workers exploitation, $p_{L} \in[0,1]$ is the degree of protection accorded to workers by employment law. In our model, employment law is understood to either prevent exploitation outright (e.g. by making it hard or costly to make workers redundant), or by giving considerable bargaining powers to workers and unions, such as mandatory codetermination, consultation requirements, or the requirement to negotiate a costly social plan for redundant employees. $c_{L}$ is the amount of resources spent to expropriate the workers and $\gamma^{\prime}>0, \gamma^{\prime \prime}<0, \lim _{c_{L} \rightarrow \infty} \gamma\left(c_{L}\right)=\varpi$. Depending on the particular circumstances of the case (explained below), this cost will be borne by the firm or by the manager himself.

Once the wages have been paid, what remains are the profits:

$$
\pi=(1-\omega) x(e)-c_{c}-c_{L} .
$$

Profits have to be shared between the manager and minority shareholders. The manager can spend resources to expropriate minority shareholders. The amount of dividends earned by minority shareholders is $d_{m}=f \pi$, where $f=(1-\bar{f})-\left(1-p_{c}\right) \delta\left(c_{c}\right) . \bar{f} \in[0,1]$ is the share of capital ${ }^{7}$ owned by the manager, $p_{c} \in[0,1]$ is the degree of protection accorded to minority shareholders by corporate law. The rules of corporate law we attempt to capture are the ones usually described as "shareholder protection" in the literature, such as the ones preventing or penalizing asset diversion or dilution of stock value (see generally Djankov et al., 2008). $c_{c}$ is the amount of resources devoted to minority shareholder exploitation. We also assume that the marginal return from expropriation is decreasing 8 : $\delta^{\prime}>0, \delta^{\prime \prime}<0, \lim _{c_{c} \rightarrow \infty} \delta\left(c_{c}\right)=1$.

Workers' effort For sake of simplicity, let us assume that $x(e):=\sqrt[2]{e}$. In this case the worker will choose the optimal amount of effort in order to maximize his own utility

$$
e^{*}=\arg \max u=w(e)-e
$$

\footnotetext{
${ }^{7}$ We use the term capital with reference to the amount of cash flow rights in the hand of the controller. The amount of cash flow right in the hand of a controlling shareholder may be substantially different from his voting rights in the case of pyramids, cross-ownership and dual class share structures; in some cases it may be possible to control the company with only a small share in cash flow rights. See Bebchuk et al. (2000)

${ }^{8} \mathrm{Or}$, in other words, we are assuming that the marginal cost of expropriation is increasing.
} 
Thus

$$
\begin{aligned}
e^{*}\left(c_{L}, p_{L}\right) & =\frac{1}{4}\left[\varpi-\left(1-p_{L}\right) \gamma\left(c_{L}\right)\right]^{2} \\
x^{*}\left(c_{L}, p_{L}\right) & =\frac{1}{2}\left[\varpi-\left(1-p_{L}\right) \gamma\left(c_{L}\right)\right]
\end{aligned}
$$

This implies that both the effort provided by the workers and the productivity of the firm are affected by the degree of labor protection, but are not affected by the degree of minority protection. The reason why we have chosen this formulation is mainly for sake of simplicity.

If this is the case, then the manager will choose the level of worker expropriation according to the effects he expects on the effort provided by the workers.

Subsequent analysis Using this framework, we analyze the interaction between labor law and minority shareholder protection. In particular, we argue that these two bodies of law interact so that

1. when the degree of shareholder protection changes (e.g. as the result of a change of corporate law), the amount of worker exploitation is affected as well. Likewise, when the degree of workers protection is changed, the amount expropriated from minority shareholder is also affected.

2. the exact type of interaction between these two bodies of law is firm specific and depends on the type of the governance structure.

3. a change in ownership concentration (mediated by labor and minority protection) does not affect the expropriation of workers in all firms. The extent depends on the existence of private costs of expropriating workers.

Furthermore, our analysis shows the significance of the size of the controlling block on the expropriation of workers, and the importance of who bears the cost of expropriation of either of the two "weak" groups.

In the following sections, we distinguish various cases, each of which is interpreted to represent specific types of firms. The cases are distinguished on the basis of whether managers personally bear a cost of expropriating (minority) shareholders and/or employees. Within each section, we can distinguish between firms where managers own only a small stake (dispersed ownership) and firms where they own a large one (concentrated ownership) if the version of the model lends itself to a real-life interpretation. In either case, a private cost of expropriation that cannot be shifted to the firm protects both minority shareholders and employees.

\subsection{Type 1. Firms controlled by financial investors}

In the first case, the cost of both expropriating shareholders and of exploiting workers is borne by the firm and no private costs are paid directly by the 
manager. There is no private cost of expropriating either minority shareholders or labor. Typically, tunneling transactions out of the firm that will harm small shareholders (both under dispersed and under concentrated ownership) will require complex transactions, and the advice of skilled professionals (such as lawyers or accountants) how to circumvent the law. Part of the resources spent on tunneling will therefore not correspond to an advantage to the manager, but simply be a deadweight loss. The same may apply with regard to the expropriation of workers. Firing workers, or even just threatening them with redundancy e.g. to obtain concession from a union, may result in transitory costs, such as reassignment of tasks within the firm or transaction costs resulting from negotiations. We assume that all of these costs are borne by the firm, i.e. the manager has no personal cost. There is not even a non-pecuniary cost from reduced reputation or from violations of social norms. Thus, the manager does not care whether employees or shareholders suffer because his personal wealth is not affected.

In cases of concentrated ownership, a plausible interpretation could be that controlling shareholder is a financial investor, such as a private equity investor, who is only interested in profits. Since the fund does not care about the nonmonetary benefit of control and has direct power over the manager, it can divert company resources and use them to cover the costs of exploiting workers and minority shareholders.

In a firm with dispersed ownership, managers would have no social norms reinforcing long-term interaction with workers, and no interest in empire-building. The manager also does not have to fear any indirect repercussions from harming shareholders.

Result 1 In the absence of private costs of expropriation, there only a partial interrelation between the effects of corporate law and employment law.

1. If minority shareholder protection increases, the share of minority dividends expropriated by the manager decreases, but the expropriation of workers is unaffected.

2. If labor protection increases, both the share of wages expropriated and the share of minority dividend expropriated are affected. The share of wage expropriated decreases. The share of minority dividend expropriated decreases if the labor share is large $(\omega>1 / 2)$ but grows if the labor share is small $(\omega<1 / 2)$.

3. If the share of cash flow rights in the hands of the financial investor $(\bar{f})$ increases then the expropriation of workers is unaffected but the degree of minority expropriation decreases.

Proof. The maximization problem faced by the manager is

$$
\max _{c_{c}, c_{L}} D_{L}=(1-f) \pi
$$




$$
\max _{c_{c}, c_{L}} D_{L}=\left[\bar{f}+\left(1-p_{c}\right) \delta\left(c_{c}\right)\right]\left[\left(1-\varpi+\left(1-p_{L}\right) \gamma\left(c_{L}\right)\right) x(e)-c_{c}-c_{L}\right]
$$

then the first order conditions are

$$
\begin{aligned}
\delta^{\prime}\left(c_{c}\right) & =\frac{\bar{f}+\left(1-p_{c}\right) \delta\left(c_{c}\right)}{\left(1-p_{c}\right)\left[\left(1-2 x^{*}\right) x^{*}-c_{c}-c_{L}\right]} \\
\gamma^{\prime}\left(c_{L}\right) & =\frac{4}{\left(1-p_{L}\right)\left(2 x^{*}-1\right)}
\end{aligned}
$$

1) If $p_{c}$ increases, $\delta^{\prime}$ must increase and $\delta\left(c_{c}\right)$ must shrink in order for equation 1 to hold true. Since $\delta^{\prime \prime}<0$, then $\delta\left(c_{c}\right)$ has to become smaller when $\delta^{\prime}$ grows. At the same time $p_{c}$ does not play any role in the first order condition for $\gamma$, hence a change in $p_{c}$ does not affect $\gamma$.

2) If $p_{L}$ grows, then both first order conditions are affected. A sufficient condition that leads to an increase of $\gamma^{\prime}$ is the increase of $p_{L}$. When $\gamma^{\prime}$ becomes larger, it leads to a reduction of $\gamma$. On the contrary $\delta^{\prime}$ becomes larger if and only if $\varpi-\left(1-p_{L}\right) \gamma\left(c_{L}\right)>1 / 2$.

3) Finally if $\bar{f}$ changes, only $\delta^{\prime}$ is affected: it has to become larger implying a reduction of $\delta$.

The effects of an increase in labor protection on the expropriation of minority crucially depend on the share of value added that is paid to workers. Intuitively, an increase of labor protection and wages paid has a twofold effect on firm's profits. On one side, an increase in wages leads to a direct reduction of profits. On the other side, the same wage increase push workers to use a higher effort that increases the value of production and profits. The net effects on profits depends on the relative size of the two effects. Since there is a decreasing marginal productivity of effort, when $\omega$ is large the effort already provided by workers is high and has a low marginal productivity. In this case a further increase in $\omega$ (due to an increase in labor protection) will usually overcome the connected increase in the value added, hence profits decrease. If profits go down, the incentive to expropriate the minority is reduced. By contrast, if $\omega$ is small the effort provided by workers is small as well and has a high marginal productivity. In this case, the increase in the value added arising from an increase in labor protection is likely to the overcome the additional wage expenses and lead to an increase of profits. If profits grow, the incentive to expropriate minority profits grows as well.

\subsection{Type 2. Publicly traded family firms / managerial firms}

In this case a private cost of expropriating workers is borne by the manager. As in the previous section, tunneling transactions will cost the firm because of the deadweight loss resulted from the necessity to devise complex transactions to conceal self-dealing as well as it will cost the exploitation of workers holdup. These monetary costs reduce firm's profits and, on the top of them, there is a 
positive private cost of exploiting employees paid by the manager, but none of expropriating minority shareholders.

Depending on the particular circumstances, there can be various institutional explanations. Our model describes two distinct corporate archetypes. First, in cases where $\bar{f}$ is high, the manager would be a controlling shareholder. More specifically, the firm could be controlled by an entrepreneurial family, which is common even in very large firms in some Continental European countries such as Italy. The literature on family firms suggests that families sometimes enjoy non-pecuniary benefits from control, such as national or regional prestige (Burkart et al., 2003). Expropriating employees could harm that reputation and make the social life of the family's members in the city or region dominated by the company less pleasant. Furthermore, entrepreneurial families may enjoy reigning over a large retinue of employees and therefore suffer a cost from if it lost some of them. ${ }^{9}$ By contrast, the controlling family may care little about the well-being of outside shareholders, which is why there is no private cost of expropriating these.

Second, where $\bar{f}$ is low, the model could apply to what is known as a BerleMeans firm (Berle \& Means, 1932), in which a publicly traded company is effectively controlled by managers holding only a small share of stocks. Blair and Stout suggest that the (legal and factual) insulation of US boards of directors (and managers) from shareholders may be efficient because it prevents holdup, thus facilitating specific investment by employees and stakeholder groups (Blair \& Stout, 1999; Blair \& Stout, 2001:438-441). Under this theory, the reason why employees trust managers is that these stand to lose something if they expropriate employees. For example, there may be social norms that encourage directors to maintain a reputation of trustworthiness. Furthermore, entrenched managers may have a taste for empire-building, which will often coincide with the interests of workers. In this interpretation of our model, $c_{L}$ would correspond to managers' costs when they forgo these possibilities and violate social norms at work in this context. In fact, there seems to be empirical evidence that at least some workers and bondholders benefit from entrenched management (Gokhale et al., 1995; Chemla, 2005:379-380). Workers and managers are thus often seen as natural allies against hostile takeovers (Pagano \& Volpin, 2005).

In our model, the personal costs of expropriation are captured by the parameter $\alpha$, which is the ratio between the the private costs borne by the manager and the costs of expropriating labor paid out the firm's cash. The larger $\alpha$ becomes, the bigger are the private costs in comparison to the direct cost of expropriation.

Note that we are not yet taking the possibility of an effective market for takeovers into account at this point. In this subgroup of cases, managers (and controlling shareholders) are fully entrenched, meaning that the desire to holdup workers will largely depend on financial incentives resulting from their ownership share. Their non-pecuniary cost protects employees from holdup.

\footnotetext{
${ }^{9}$ Similarly, the firm could be controlled by a government entity. Political decision-maker may be penalized by voters if they expropriate employees (resulting in the loss of jobs).
} 
Conceivably, the manager's private costs from expropriating workers could also be negative. This would mean that there are other factors balancing the pro-employee bias described above in the Berle-Means firm, such as social norms favoring a strong shareholder primacy norm. ${ }^{10}$

Furthermore, the existence of cost of expropriating workers also leads to a shielding effect for minority shareholders: The diminished holdup gains to shareholders also decrease the incentive to expropriate this group.

Result $\mathbf{2}$ When the cost of expropriating labor is borne by managers, the shielding effects of corporate law and employment law are interrelated. Specifically,

1. if the protection of minority shareholders increases, the share of minority dividends expropriated (by the manager) decreases and the labor expropriation is reduced as well.

2. if labor protection increases, the share of wages expropriated by the manager decreases. The share of minority dividends expropriated decreases if $\omega>1 / 2$ and grows if $\omega<1 / 2$.

3. if $\bar{f}$ increases, the rate of minority expropriation decreases and the rate of expropriation of workers increases.

4. if private costs of worker expropriation ( $\alpha$ ) increase, there is a first order reduction in worker's expropriation. There is also a second order change in the degree of minority expropriation: it decreases if $\omega>1 / 2$ and grows if $\omega<1 / 2$.

Proof. The maximization problem faced by the manager is

$$
\begin{gathered}
\max _{c_{c}, c_{L}} D_{L}=(1-f) \pi-\alpha c_{L} \\
\max _{c_{c}, c_{L}} D_{L}=\left[\bar{f}+\left(1-p_{c}\right) \delta\left(c_{c}\right)\right]\left[\left(1-\varpi+\left(1-p_{L}\right) \gamma\left(c_{L}\right)\right) x(e)-c_{c}-c_{L}\right]-\alpha c_{L}
\end{gathered}
$$

whose first order conditions are

$$
\begin{aligned}
\delta^{\prime}\left(c_{c}\right) & =\frac{\bar{f}+\left(1-p_{c}\right) \delta\left(c_{c}\right)}{\left(1-p_{c}\right)\left[\left(1-2 x^{*}\right) x^{*}-c_{c}-c_{L}\right]} \\
\gamma^{\prime}\left(c_{L}\right) & =\frac{4\left(\alpha+\bar{f}+\left(1-p_{c}\right) \delta\left(c_{c}\right)\right)}{\left(1-p_{L}\right)\left(2 x^{*}-1\right)\left(\bar{f}+\left(1-p_{c}\right) \delta\left(c_{c}\right)\right)}
\end{aligned}
$$

1) If $p_{c}$ increases, $\delta^{\prime}$ and $\gamma^{\prime}$ must increase. Since $\delta^{\prime \prime}<0$ and $\gamma^{\prime \prime}<0$ then $\delta\left(c_{c}\right)$ has to become smaller when $\delta^{\prime}$ grows and $\gamma\left(c_{L}\right)$ has to reduce since $\gamma^{\prime}$ grows, as well.

\footnotetext{
${ }^{10}$ In the case of a (partly) government-owned entity, the cost may be negative because the predominant voter preferences are against government stakes in the industry (which may often have required subsidies from tax money in the past). In such a case, the government-appointed manager may have incentives to cut labor costs.
} 
2) If $p_{L}$ grows, then both first order conditions are affected. A sufficient condition that leads to an increase of $\gamma^{\prime}$ is the increase of $p_{L}$. When $\gamma^{\prime}$ becomes larger, it leads to a reduction of $\gamma$. On the contrary $\delta^{\prime}$ becomes larger if and only if $\varpi-\left(1-p_{L}\right) \gamma\left(c_{L}\right)>1 / 2$.

3 ) If $\bar{f}$ changes, $\delta^{\prime}$ has to become larger implying a reduction of $\delta\left(c_{c}\right)$, while $\gamma^{\prime}$ has to become smaller implying an increase of $\gamma\left(c_{L}\right)$.

4) Since $\alpha$ appears only in the first order condition for $\gamma$, an increase of $\alpha$ will directly affect $\gamma$, reducing it. A reduction in $\gamma$ will lead to an increase of $\omega$ and $x$ such that $\delta^{\prime}$ will reduce if $\omega<1 / 2$ and will increase if $\omega>1 / 2$.

An important result is that workers are not only protected by employment law, but also by corporate law. The improvement in the protection of minority shareholders makes it less attractive for the manager to expropriate employees because he has to assign a larger proportion of potential holdup gains to the outside shareholders.

On the flipside of the coin, the impact of labor protection on minority shareholders is less clear: Overall, minority shareholders do not necessarily benefit from increased labor protection, since it is only their share that decreases: they could still benefit if holdup leads to an overall increase in shareholder value.

\subsection{Type 3. "Partnerships" / publicly traded firms sub- ject to a vibrant market for corporate control}

In this subsection, there is a positive private cost of expropriating minority shareholders, but none of expropriating employees. The firm directly pays the entire cost of exploiting workers (with a reduction in profits). The manager, on the other hand, has a cost of exploiting minority shareholders. In a concentrated ownership firm, this model setup could be interpreted as a professional partnership, where partners are in a long-term relationship and typically will care about each other, therefore making expropriation of other partners costly. ${ }^{11}$ On the other hand, shareholders may care little about employees (e.g. associates in a law firm, where, according to the conventional wisdom, the turnover is very high).

In the context of a publicly traded firm with dispersed ownership, the private cost of expropriating shareholders could be the result of institutions aligning the interests of managers with those of shareholders, such as a functioning system of executive compensation, or an effective market for corporate control. Arguably, such factors are much less present in one paradigmatic dispersed ownership system, the US, than it was often thought. In recent years, scholars have suggested that compensation schemes actually found in practice are rather a rent-seeking device for managers than a solution to agency problems, since managers themselves have considerable influence on the design of compensation packages (Bebchuk \& Fried, 2003). Furthermore, Delaware corporate law

\footnotetext{
${ }^{11}$ The existence of a "manager" that could exploit other partners may seem unlikely at first glance, since normally no individual partner will have a controlling stake. However, several partner could form a coalition against another one to jointly control the firm.
} 
provides nearly perfect takeover defenses, namely the combination of staggered boards and poison pills (Bebchuk et al., 2002). By contrast, takeover law in the UK, the second important dispersed ownership system, is entirely different, as the City Code on Mergers and Takeovers has provided an obligation for managers to stay neutral in takeover contests since the late 1960s (Armour \& Skeel, 2007). As a leading scholar of UK company law puts it, when facing a hostile bid, "the directors of the target are thrown back on their powers of persuasion" (Davies, 2008:987). The model could here represent a publicly traded British firm, where the directors face a more significant cost in the form of an increased probability of a hostile takeover when they expropriate minority shareholders. ${ }^{12}$

The introduction of a private cost of exploiting minority shareholders is shown by $\beta$, which is the ratio between the private cost borne by the manager alone and the one paid directly by the firm..

Result 3 When there is a private cost of expropriating shareholders, but not of employees, there is a partial interrelation between the effects of the two bodies of law.

1. If minority shareholder protection increases, then the share of minority dividends expropriated by the manager decreases, but the expropriation of labor is unaffected.

2. On the contrary, if labor protection increases both the share of wages expropriated and the share of minority dividends expropriated are affected. Labor expropriation is reduced while the effects on minority expropriation depend on the value of $\omega$. Its share grows if and only if $\omega<1 / 2$, and decreases otherwise.

3. If $\bar{f}$ increases, the rate of expropriation of workers is unaffected, but the rate of minority expropriation becomes smaller.

4. If private losses of shareholders expropriation $(\beta)$ increase, there is a reduction in minority expropriation.

Proof. The maximization problem faced by the manager is

$$
\begin{gathered}
\max _{c_{c}, c_{L}} D_{L}=(1-f) \pi-\beta c_{c} \\
\max _{c_{c}, c_{L}} D_{L}=\left[f+\left(1-p_{c}\right) \delta\left(c_{c}\right)\right]\left[\left(1-\varpi+\left(1-p_{L}\right) \gamma\left(c_{L}\right)\right) x(e)-c_{c}-c_{L}\right]-\beta c_{c} \\
\delta^{\prime}\left(c_{c}\right)=\frac{\beta+\bar{f}+\left(1-p_{c}\right) \delta\left(c_{c}\right)}{\left(1-p_{c}\right)\left[\left(1-2 x^{*}\right) x^{*}-c_{c}-c_{L}\right]} \\
\gamma^{\prime}\left(c_{L}\right)=\frac{4}{\left(1-p_{L}\right)\left(2 x^{*}-1\right)}
\end{gathered}
$$

\footnotetext{
${ }^{12}$ Social norms may also play a role here. Bainbridge (Bainbridge, 2003:582) claims that it is largely a social norm of shareholder primacy (and not the market for corporate control) that keeps US directors aligned with shareholder interests.
} 
1) If $p_{c}$ increases, $\delta^{\prime}$ must increase. Since $\delta^{\prime \prime}<0$, then $\delta\left(c_{c}\right)$ has to become smaller when $\delta^{\prime}$ grows. At the same time $p_{c}$ does not play any role in the first order condition for $\gamma$, hence a change in $p_{c}$ does not affect $\gamma$.

2) If $p_{L}$ grows, then both first order conditions are affected. A sufficient condition that leads to an increase of $\gamma^{\prime}$ is the increase of $p_{L}$. When $\gamma^{\prime}$ becomes larger, it leads to a reduction of $\gamma$. However, $\delta^{\prime}$ becomes larger if and only if $\varpi-\left(1-p_{L}\right) \gamma\left(c_{L}\right)>1 / 2$.

3) If $\bar{f}$ changes, $\delta^{\prime}$ has to become larger implying a reduction of $\delta\left(c_{c}\right)$, while $\gamma^{\prime}$ is not affected.

4) Since $\beta$ appears only in the first order condition for $\delta$, an increase of $\alpha$ will directly affect $\delta$, reducing it. A reduction in $\delta$ does not affect $\gamma$ since it does not affect $x^{*}$.

\subsection{Type 4. Closely-held family firms / publicly traded firms subject to a vibrant market for corporate control}

In this case, there is a private cost of expropriating either minority shareholders or labor, i.e. the manager pays private costs both of exploiting workers and minority shareholders.

In the concentrated ownership situation, the most intuitive interpretation would seem to be a closely-held family firm. Minority shareholders who may be exploited may be family members or friends with a long-standing social relationship to the manager. The manager's utility function would therefore also be altruistic with respect to this group. Furthermore, as a leading member of the entrepreneurial family, he also cares about the well-being of long-term employees he closely interacts with on a day-to-day basis, and draws non-pecuniary benefits from the family's social standing in the town where the company is located.

The dispersed ownership case of this version of the model resembles that of the previous section, with the exception of the additional private cost of "exploiting" workers. The manager may still be subject to a vibrant market for corporate control (represented by the private cost of expropriating shareholders), but at the same time care about the well-being of workers, e.g. because of countervailing social norms. The exact effects will depend on the relative magnitude of these effects.

Conceivably, the costs of exploiting either shareholders or workers could also be negative. For example, the cost of exploiting minority shareholders could be negative because the shareholder-manager tunneling assets out of the firm could have an advantage the firm does not have, e.g. resulting from synergy effects that increase the value of assets when used outside the firm. In the case of a negative cost of exploiting employees, he would reap an additional benefit when they expropriate employees, e.g. because the market for corporate control creates a particularly high probability of being ousted by a hostile bidder

Result 4 When the manager faces both private cost of expropriating minority and labor, then there is an interrelation between the effects of the two bodies of law. Specifically, 
1. if minority shareholders protection increases, both the share of wages expropriated by the manager and the share of minority dividends expropriated (by the manager) decrease;

2. if labor protection increases, the share of wages expropriated by the manager decreases, while the effect on minority expropriation depends on the value of $\omega$. Minority expropriation decreases if and only if $\omega<1 / 2$. It grows in the opposite case;

3. if $\bar{f}$ increases, the rate of minority expropriation decreases and the rate of workers expropriation increases.

4. if private costs of worker expropriation ( $\alpha$ ) increase, there is a first order reduction in expropriation of workers and a second order change in shareholder expropriation: it increases if $\omega<1 / 2$ and decreases otherwise.

5. if private costs of shareholders expropriation $(\beta)$ increase, there is a first order reduction in minority expropriation and a second order reduction in labor expropriation;

Proof. The maximization problem faced by the manager is

$$
\begin{gathered}
\max _{c_{c}, c_{L}} D_{L}=(1-f) \pi-\beta c_{c}-\alpha c_{L} \\
\max _{c_{c}, c_{L}} D_{L}=\left[\bar{f}+\left(1-p_{c}\right) \delta\left(c_{c}\right)\right]\left[\left(1-\varpi+\left(1-p_{L}\right) \gamma\left(c_{L}\right)\right) x(e)-c_{c}-c_{L}\right]+ \\
-\beta c_{c}-\alpha c_{L} \\
\delta^{\prime}\left(c_{c}\right)=\frac{\beta+\bar{f}+\left(1-p_{c}\right) \delta\left(c_{c}\right)}{\left(1-p_{c}\right)\left[\left(1-2 x^{*}\right) x^{*}-c_{c}-c_{L}\right]} \\
\gamma^{\prime}\left(c_{L}\right)=\frac{4\left(\alpha+\bar{f}+\left(1-p_{c}\right) \delta\left(c_{c}\right)\right)}{\left(1-p_{L}\right)\left(2 x^{*}-1\right)\left(\bar{f}+\left(1-p_{c}\right) \delta\left(c_{c}\right)\right)}
\end{gathered}
$$

1) If $p_{c}$ increases, $\delta^{\prime}$ and $\gamma^{\prime}$ must increase. Since $\delta^{\prime \prime}<0$ and $\gamma^{\prime \prime}<0$ then $\delta\left(c_{c}\right)$ has to become smaller when $\delta^{\prime}$ grows and $\gamma\left(c_{L}\right)$ has to reduce since $\gamma^{\prime}$ grows, as well.

2) If $p_{L}$ grows, then both first order conditions are affected. A sufficient condition that leads to an increase of $\gamma^{\prime}$ is the increase of $p_{L}$. When $\gamma^{\prime}$ becomes larger, it leads to a reduction of $\gamma$. On the contrary, $\delta^{\prime}$ becomes larger if and only if $\varpi-\left(1-p_{L}\right) \gamma\left(c_{L}\right)>1 / 2$, since a reduction of $\gamma$ increases wages and lead to an increase of $x^{*}$.

3) If $\bar{f}$ changes, $\delta^{\prime}$ has to become larger implying a reduction of $\delta\left(c_{c}\right)$, while $\gamma^{\prime}$ has to become smaller implying an increase of $\gamma\left(c_{L}\right)$.

4) Since $\alpha$ appears only in the first order condition for $\gamma$, an increase of $\alpha$ will directly affect $\gamma$, reducing it. A reduction in $\gamma$ will lead to an increase of $\omega$ and $x$ such that $\delta^{\prime}$ will decrease if $\omega<1 / 2$ and will increase if $\omega>1 / 2$. 
5) Since $\beta$ appears only in the first order condition for $\delta$, an increase of $\alpha$ will directly affect $\delta$, reducing it. A reduction in $\delta$ does not affect $\gamma$ since it has no effect on the size of $x^{*}$.

\section{Comparative observations}

As we have seen, the effects of changes in shareholder protection, labor protection, and concentration of ownership depend on the structure of the firm and the respective private costs of expropriation. The following table summarize some of the results.

\begin{tabular}{|l|l|l|l|}
\hline & $\begin{array}{l}\text { Higher minority } \\
\text { protection }\end{array}$ & Higher labor protection & $\begin{array}{l}\text { Higher ownership } \\
\text { concentration }\end{array}$ \\
\hline $\begin{array}{l}\text { Type 1 } \\
\text { no private cost }\end{array}$ & lower minority expr. & $\begin{array}{l}\text { 1. ambiguous change } \\
\text { in minority expr. } \\
2 . \text { lower labor expr. }\end{array}$ & lower minority expr. \\
\hline $\begin{array}{l}\text { Type 2 } \\
\text { private costs } \\
\text { of expr. labor }\end{array}$ & 1. lower minority expr. & $\begin{array}{l}\text { 1. ambiguous change } \\
\text { in minority expr. }\end{array}$ & $\begin{array}{l}\text { 1. lower minority expr. } \\
\text { 2. higher labor expr. }\end{array}$ \\
\hline $\begin{array}{l}\text { Type 3 } \\
\text { private costs of } \\
\text { minority expr. }\end{array}$ & lower minority expr. & $\begin{array}{l}\text { 1. ambiguous change } \\
\text { in minority expr. }\end{array}$ & lower minority expr. \\
\hline $\begin{array}{l}\text { Type 4 } \\
\text { private costs } \\
\text { of both expr. }\end{array}$ & 1. lower minority expr. & $\begin{array}{l}\text { 1. ambiguous change } \\
\text { in minority expr. }\end{array}$ & $\begin{array}{l}\text { 1. lower minority expr. } \\
\text { 2. lower labor expr. }\end{array}$ \\
\hline
\end{tabular}

The first result of our model is that changes in the level of labor and minority protection may affect also players different from the ones that the law is supposed to target. A change in minority protection may affect the behavior of the manager in respect of the workers, and vice-versa a change in the level of labor protection may affect the degree of minority shareholder expropriation in a significant way. This is one of the reason why we argue that policy making in the two bodies of law should be coordinated in order to not give the wrong incentives to managers.

Countries with strong shareholder protection tend to have weak protection of labor, and vice versa (Roe, 2002:263-264;La Porta et al., 2008:311;Belloc \& Pagano, 2009). To a certain extent, our model confirms that shareholder protection and labor protection may sometimes serve as substitutes: as long as there is a private cost of exploiting workers, they will benefit from either. The reason why they benefit from minority protection is that the manager would have to share a larger proportion of holdup gains (and out of cash box cost of expropriation) with minority shareholders. His inability to reap all of these gains reduces his incentive to harm workers given his unchanged private cost. As said, this result holds only where the is a positive cost of expropriating labor, 
as in the case of a controlling family or insulated managers that identify with employees e.g. because of social norms. These might be the circumstances, where, according to some scholars' claims, investors and employees occasionally engage in political coalitions against management (Gourevitch \& Shinn, 2005:65$67)$.

While labor protection naturally improves the position of labor, its effects for investors are mixed: Depending on the circumstances, they may benefit from it, or sustain harm. When either is likely to occur depends on the baseline expectations of labor about the distribution of rents produced by the company. If these are low, the marginal benefit of increasing labor protection for profits is high, which also increases the incentive of the controller to expropriate minority shareholders. Particularly when minority protection is low, controlling shareholders (managers) might have a joint interest in increasing labor protection, to the detriment of minority investors. What will happen over time will of course depend on political processes and on how employees' baseline expectation about their share in corporate rents is formed. Assuming, for example, a continuous increase in labor protection (due to joint lobbying by controlling shareholders and labor unions) that is accompanied by a concurrent (or even stronger) increase in employees' expectations, a corporate governance system will eventually reach a point where the marginal effects of labor protection on profits are negative, in which managers will rather side with minority shareholders against labor and lobby for the reduction of labor protection. This may be one reason for increasing efforts to reduce labor protection in Europe since the 1990s after decades during which labor rights were strengthened.

Most importantly for the point originally motivating the paper, the model also illustrates that a change in the ownership that leads to a higher (lower) concentration is associated with an augmented (reduced) degree of expropriation of workers only when there is a private cost of expropriating workers. If the private cost of expropriating labor does not exist the owner will choose the same degree of workers' expropriation regardless of his share in the company. The private cost inhibits expropriation because of its countervailing incentive. In the case of a larger ownership share, the manager has a greater financial incentive to exploit workers, which is why the private cost factor is more likely overcome. By contrast, if ownership concentration increases, the degree of exploitation of minority shareholders always decreases. The simple intuitive explanation is that the amount that can be gained decreases with the minority's ownership share, so that the benefits are no longer made up by the cost (irrespective of whether they are borne by the firm or the manager).

For the question whether controlling shareholders or "independent" managers are better able to bond with stakeholders and incentivize them to make specific investment, the answer is (trivially) that in principles it is managers, since they have no financial gain from creating hold up situations that harm stakeholders. However, there are many factors that complicate the issue, which we have interpreted as private costs of expropriation that shield workers from holdup (such as social norms or idiosyncratic preferences of controlling families). The shielding effect may be turned into its opposite if managers are particularly 
attuned to shareholder interests for institutional reasons.

\section{Conclusion}

Our paper has attempted to elucidate factors that may eliminate incentives for controlling shareholders and managers to engage in self-dealing behavior to the detriment of minority shareholders and in taking holdup and other opportunities to exploit stakeholders, particularly labor. In particular, the previous literature has often assumed that either managers of Berle-Means firms or large blockholders are better able to provide credible commitment that allows stakeholders to make firm-specific investment. Large ownership stakes may of course create an incentive to exploit labor, since the financial benefit from it is comparatively large. However, the most important factor for both managers or blockholders is private costs of expropriation. For example, the CEO of a managerial firm may enjoy empire-building or social prestige from controlling a large number of employees, which will create a disincentive against holding up labor. Similarly, a blockholding family may enjoy social prestige within the local community, as a result of which they will refrain from exploiting labor's firm-specific investment. For analytical purposes, we have also extended the concept of costs of expropriation to the exploitation of minority shareholders through private benefits of control. For example, in a family firm, the controlling shareholder member may be reluctant to expropriate his family members because he fears social repercussions.

\section{References}

[Aguilera \& Jackson, 2003]

[Armour \& Deakin, 2003]

[Armour \& Skeel, 2007]

Aguilera, R. \& Jackson, G. (2003). The Cross-National Diversity of Corporate Governance: Dimensions and Determinants, Academy of Management Review, 28, 447-465.

Armour, J. \& Deakin, S. (2003). Insolvency and employment protection: the mixed effects of the Acquired Rights Directive, International Review of Law and Economics, 22, 443-463.

Armour, J. \& Skeel, D. (2007). Who Writes the Rules for Hostile Takeovers, and Why? The Peculiar Divergence of US and UK Takeover Regulation. Georgetown Law Journal, 95, 17271794. 
[Bainbridge, 2003]

[Bebchuk et al., 2002]

[Bebchuk \& Cohen, 2005]

[Bebchuk \& Fried, 2003]

[Bebchuk et al. (2000)]

[Belloc \& Pagano, 2009]

[Berle \& Means, 1932]

[Blair \& Stout, 1999]

[Blair \& Stout, 2001]
Bainbridge, S. (2003). Director Primacy: The Means and Ends of Corporate Governance, Northwestern University Law Review, 97, 547-606.

Bebchuk, L., Coates, C. \& Subramanian, G. (2002). The Powerful Antitakeover Force of Staggered Boards: Theory, Evidence, and Policy. Stanford Law Review, 54, 887-951.

Bebchuk, L. \& Cohen, A. (2005). The cost of entrenched boards. Journal of Financial Economics, 78, 409-433.

Bebchuk, L. \& Fried, J. (2003). Executive Compensation as an Agency Problem. Journal of Economic Perspectives, 17, 71-92

Bebchuk, L., Kraakman, R. \& Triantis, G. (2000). Stock Pyramids, CrossOwnership, and Dual Class Equity: The Mechanisms and Agency Costs of Separating Control from Cash-Flow Rights. In R. Morck (Ed.), Concentrated Corporate Ownership (pp. 295318), Chicago and London, The University of Chicago Press.

Belloc, M. \& Pagano U. (2009). Coevolution of Politics and Corporate Governance, International Review of Law and Economics, 29, 106-114.

Berle, A. \& Means, G. (1932). The Modern Corporation and Private Property. New York, MacMillan.

Blair, M. \& Stout, L. (1999). A Team Production Theory of Corporate Law. Virginia Law Review, 85, 247-328.

Blair, M. \& Stout, L. (2001). Director Accountability and the Mediating Role of the Corporate Board. Washington University Law Quarterly, 9, 403447. 
[Blair \& Stout, 2006]

[Brealey et al., 2006]

[Burkart et al., 1997]

[Burkart et al., 2003]

[Charreaux \& Desbrières, 2001]

[Chemla, 2005]

[Davies, 2008]

[Djankov et al., 2008]

[Elhauge, 2005]

[Fauver \& Fuerst, 2006]
Blair, M. \& Stout, L. (2006). Specific Investment and Corporate Law. European Business Organization Law Review, 7, 473-500.

Brealey, R., Myers, S. \& Allen, F. (2006). Principles of Corporate Finance, 8th. ed., Boston, McGraw-Hill Irwin.

Burkart, M., Gromb, D. \& Panunzi, F. (1997). Large Shareholders, Monitoring, and the Value of the Firm. Quarterly Journal of Economics, 112, 693728.

Burkart, M., Panunzi, F.. \& Shleifer, A. (2003). Family Firms, Journal of Finance, 48, 2167-2201.

Charreaux, G. \& Desbrières, P. (2001). Corporate Governance: Stakeholder Value versus Shareholder Value. Journal of Management and Governance, 5, 107-128.

Chemla, G. (2005). Hold-up, stakeholders and takeover threats. Journal of Financial Intermediation, 14, 376-397.

Davies, P. (2008). Gower and Davies' Principles of Modern Company Law, 8th ed., London, Sweet \& Maxwell.

Djankov, S., La Porta, R., Lopez-deSilanes, F. \& Shleifer, A. (2008). The Law and Economics of Self-Dealing. Journal of Financial Economics, 88, 430-465.

Elhauge, E. (2005). Sacrificing Profit in the Public Interest. New York University Law Review, 80, 733-869.

Fauver, L. \& Fuerst, M. (2006). Does good corporate governance include employee representation? Evidence from German corporate boards, Journal of Financial Economics, 82, 673-710. 
[Franks \& Mayer, 1998]

[Gelter, 2009]

[Gokhale et al., 1995]

[Gourevitch \& Shinn, 2005]

[Habib, 1997]

[Hansmann \& Kraakman, 2004]

[Jackson, 2005]

[La Porta et al., 2008]
Franks, J. \& Mayer, C. (1998). Ownership and Control in Europe, in P. Newman (Ed.), The New Palgrave Dictionary of Economics and the Law, Vol. 2 (pp. 722-730), London, Macmillan.

Gelter, M. (2009). The Dark Side of Shareholder Influence: Managerial Autonomy and Stakeholder Orientation in Comparative Corporate Governance, Harvard International Law Journal, 50, 129-194.

Gokhale, J., Groshen, E. \& Neumark, D. (1995). Do Hostile Takeovers Reduce Extramarginal Wage Payments? The Review of Economics and Statistics, 77, 470-485.

Gourevitch, P. \& Shinn, J. (2005). Political Power and Corporate Control, Princeton, New Jersey, Princeton University Press.

Habib, M. (1997). Monitoring, Implicit Contracting, and the Lack of Permanence of Leveraged Buyouts, European Finance Review, 1, 139-163.

Hansmann, H. \& Kraakman, R. (2004). The Basic Governance Structure, in Kraakman, R., Davies, P., Hansmann, H., Hertig, G., Hopt, K., Kanda, H. \& Rock, E., The Anatomy of Corporate Law (pp. 33-70), Oxford, Oxford University Press.

Jackson, G. (2005). Employee Representation on the Board Compared: A Fuzzy Sets Analysis of Corporate Governance, Unionism and Political Institutions, Industrielle Beziehungen, 12, 1-28.

La Porta, R., Lopez-de-Silanes, F. \& Shleifer, A. (2008). The Economic Consequences of Legal Origins, Journal of Economic Literature, 46, 285-332. 
[Pagano \& Volpin, 2005]

[Pagano \& Volpin, 2008]

[Rajan \& Zingales, 1998]

[Roe, 2002]

[Roe, 2003]

[Shleifer \& Summers, 1988]

[Shleifer \& Vishny, 1997]

[Woolcock, 1996]
Pagano, M. \& Volpin, P. (2005). Managers, Workers, and Corporate Control, Journal of Finance, 60, 841-868.

Pagano, M. \& Volpin, P. (2008). Labor and Finance, Working Paper.

Rajan, R. \& Zingales, L. (1998). Power in a Theory of the Firm, Quarterly Journal of Economics, 113, 387-432.

Roe, M. (2002). Corporate Law's Limits, Journal of Legal Studies, 31, 233271.

Roe, M. (2003), Political Determinants of Corporate Governance, Oxford, Oxford University Press.

Shleifer, A. \& Summers, L. (1988). Breach of Trust in Hostile Takeovers. In A. Auerbach (Ed.), Corporate Takeovers. Causes and Consequences (pp. 33-67), Chicago, University of Chicago Press.

Shleifer, A. \& Vishny, R. (1997). A Survey of Corporate Governance, Journal of Finance, 52, 737-783.

Woolcock, S. (1996). Competition among Forms of Corporate Governance in the European Community: The Case of Britain. In S. Berger \& R. Dore (Eds.), National Diversity and Global Capitalism (pp. 179-196), Ithaca and London, Cornell University Press. 


\section{about ECGI}

The European Corporate Governance Institute has been established to improve corporate governance through fostering independent scientific research and related activities.

The ECGI will produce and disseminate high quality research while remaining close to the concerns and interests of corporate, financial and public policy makers. It will draw on the expertise of scholars from numerous countries and bring together a critical mass of expertise and interest to bear on this important subject.

The views expressed in this working paper are those of the authors, not those of the ECGI or its members. 


\section{ECGI Working Paper Series in Law}

\section{Editorial Board}

Editor

Consulting Editors
Guido Ferrarini, Professor of Law, University of Genova \& ECGI

Theodor Baums, Director of the Institute for Banking Law, Johann Wolfgang Goethe University, Frankfurt \& ECGI

Paul Davies, Cassel Professor of Commercial Law,

London School of Economics and Political Science \& ECGI

Henry B Hansmann, Augustus E. Lines Professor of Law, Yale Law School \& ECGI

Klaus J. Hopt, Director, Max Planck Institute for Foreign Private and Private International Law \& ECGI

Roberta Romano, Allen Duffy/Class of 1960 Professor of Law, Yale Law School \& ECGI

Eddy Wymeersch, Professor of Commercial Law, University of Ghent \& ECGI

Editorial Assistant : $\quad$ Paolo Casini, "G.d'Annunzio" University, Chieti \& ECARES, Lidia Tsyganok, ECARES, Université Libre De Bruxelles 


\section{Electronic Access to the Working Paper Series}

The full set of ECGI working papers can be accessed through the Institute's Web-site (www.ecgi.org/wp) or SSRN:

Finance Paper Series http://www.ssrn.com/link/ECGI-Fin.html

Law Paper Series http://www.ssrn.com/link/ECGI-Law.html 